Orissa Journal of Commerce

Vol. 42, Issue 3, July-September 2021

ISSN: 0974-8482

(C) OJC India. All Right Reserved

URL: www.ojcoca.org

DOI: https://doi.org/10.54063/ojc.2021.v42i03.03

\title{
Trends and Determinants of Primary Market Activities: Evidences from India
}

\author{
Lovleen Gupta ${ }^{1}$ and Sheetal Maurya ${ }^{2 *}$ \\ ${ }^{1}$ Assistant Professor, Hindu College, University of Delhi,Delhi.E-mail: Lovleen15_gupta@yahoo.co.in \\ ${ }^{2}$ Assistant Professor, College of Vocational Studies, University of Delhi \& Research Scholar, Department of Commerce, \\ Delhi School of Economics, Delhi. E-mail: sheetal.maurya17@gmail.com \\ ${ }^{*}$ Corresponding Author
}

To cite this paper

Gupta, L., \& Maurya, S. (2021).

Trends and Determinants of

Primary Market Activities:

Evidence from India. Orissa Journal

of Commerce. 42(3), 27-41.

Keywords

Primary market, Market timing, Initial public offerings, Investor sentiments, Market PE ratio

JEL Classification G100, G120, G190, G240, G400, G410

\section{Introduction}

Worldwide IPO based financing gained momentum during the period of 2004-2007 and one of the major contributors to this was emerging markets including India (Meluzín and Zinecker, 2013). Undeniably India is an attractive investment destination for foreign institutional and portfolio investors and the primary market plays a crucial role in channelizing the developmental capital.The number of initial public offerings in India has grown at a compounded annual growth rate of $7.1 \%$ over the last two decades. Banking, cement and construction, telecommunication, power, and other financial institutions are the top mobilizers of funds. Over the past few decades, Indian primary market has gone through remarkable regulatory reforms in direction of investor protection and improving market efficiency (Maurya, 2017). These efforts in direction of making the Indian capital market accessible to investors and issuers have resulted in improved liquidity of the overall market.At the same time, capital market reforms in conjunction with the latest regulatory changes in the Indian Companies Act 2013

Orissa Journal of Commerce, 42(3) (C) 2021 
has been imperative in emphasizing the importance of strong corporate governance as it has been observed in the past that many of the firms that came up with initial public offerings were fly-by-night fundamentally weak companies.

Therefore, stringent regulatory measures were implemented by the Security Exchange Board of India (SEBI) to protect the investors' interests. Since then, several researches have been conducted to study the impact of various regulatory and governance reforms on the primary market and initial public offering market particularly. For instance, Singh et al. (2019) investigated the predictive power of various board-related governance variables and reported that the nature of board leadership can be a significant predictor of the initial day listing gains. In another study, Singh and Maurya (2018)analyzed the role of governance variables and ownership structure in determining the underpricing of initial public offerings in India.

The Indian new issue market has two key characteristics; the first is the presence of significant listing gains due to IPO underpricing. However, superior listing day returns are no guarantee of a greater return in long term. Gupta et al. (2020) investigated the long-run operating performance of IPOs and reported that the firms that give significant listing day returns are more likely to have a positive return on net worth and earning per share in the long run (3 years post listing). Several studies have been conducted in past to investigate the reasons for IPO underpricing. Second, the dominance of the private sector over the public sector in the new issue market. Approximately $93 \%$ of the public offerings over the past two decades were from private sector firms. However, the public sector still mobilises far more aggregate funds than the private sector. Therefore, the average issue size of public sector firms is higher than that of private-sector firms. In terms of sectoral concentration banks/FIs, information \& technology, textile, cement \& construction, and telecommunications are the key sectors. Further, variability in public sector issues in terms of the number of offering per year and the issue size is far greater than the private sector.

Addressing these peculiarities on the Indian capital market the present study attempts to study the growth and development in primary market activities in India through trend analysis for the period of 1997-2020. The trends and developments are analysed through two major sections viz. descriptive analysis and historical trend analysis. The descriptive statistics analysis section covers industry-wise, sector-wise, and instrument-wise developments over the period of study. And historical trend analysis uses semi-log regression equations to study the growth rate in the number of IPOs and the amount of funds raised via IPOs. To get a comparative view, the growth rate in FPOs and Right Issues is also studied on identical variables. This section also investigates the market-related determinants i.e., investor sentiment and market valuation and that affect the level of primary market activities. For the present study, historical data has been collected from the annual report of SEBI. The sample comprised of 23 years of data from 1997-2020. The data for years before 1997 could not be collected due to its unavailability.

\section{Literature Review and Theoretical Background}

The primary market provides an important channel for mobilization of developmental capital. Private firms in need of funds that want to raise capital through the issuance of equity can opt for initial 
public offerings, public firms in need of development capital firms may also come up with a follow-on public offering or right issues. The extant literature provides plenty of evidence on the presence of market timing at the time of initial public offering. However, the literature lacks evidence on market timing and determinants of follow-on public offerings and right issues.

Researches document an increase in the number of public offerings during the period of economic expansion called 'hot market' and a decline in the number of public offerings during 'cold market' due to economic contraction. Baker and Wurgler (2000)documented that firms are more likely to go for a public offering than a debt issue just prior to the period of low equity return. This, implies the presence of market timing of equity issues as during the hot market cost of equity falls. Similar evidences have been reported in several other studies as well. For instance, Ritter (1984); Loughran and Ritter (1995); Ritter and Welch (2002); Rajan and Servaes (1995)and Burgstaller (2003) documented that firms time the issue of equities to take advantage of favourable market conditions. However, hot issue market not necessarily coincide with urgent fund requirements or future investment opportunity (Loughran $e t$ al. 1994). Similarly, Alti (2005) and Benninga et al. (2005) emphasized that public offerings tend to cluster around time and industry. Lowry and Schwert (2002)also reported that similar firms tend to go public during the same time. Therefore, variability in IPO volume is affected by not only the financing requirements of the issuing firm but also the prevailing market condition.

Among these economically significant variables, investor sentiments, informational asymmetry, and demand for capital are the most prominent (Lowry, 2003; He, 2007). It is usually more attractive for issuers to raise capital during the period of high stock market valuation due to the low cost of equity owing to the high investor optimism. Burgstaller (2009) found that prevailing interest rates and corporate indebtedness are significant determinants of seasoned equity offerings in both statistical and economic terms. Results of a survey with 336 CEOs conducted by Brau and Fawcett (2004) confirms that prevailing market condition plays a crucial role in timing the public offering.

Therefore, this study attempts to analyse the historical trend in the volume of primary market activities along with the market-related variables. Although it has been proposed and documented by several researchers that, public offerings are timed to capitalize on the favourable market conditions, some have even argued that firms may still decide to go with public offerings during an economic downturn despite the huge uncertainty and associated risk. One justification for this could be the expectation of market inversion. A prolonged negative performance (over two years or more) of the market is viewed to be the result of overreaction. Hence, issuers may come out with public offerings even during a weak market in expectation of reversal in the future (Batnini and Hammami, 2015).

Latham and Braun (2010) investigated the role of CEO ownership and leverage in the likelihood of going public during a period of economic downturn. The study documented an inverse U shape relationship between CEO ownership and the likelihood of going through a successful IPO. Further, firms with high leverage tend to continue with the decision to launch IPO even during the less favourable market conditions. Babich and Sobel (2004) documented that firms try to maximize the present value of IPO proceeds and so the decision about the amount of funds to be raised is largely affected by the firm's size, recent performance, and prevailing market conditions. In addition to the existing literature on determinants of volatility in IPO trends and volume, Blum (2011) particularly focused on factors 
discriminating the firms going public during the economic downturn from those waiting for the economy to recover. The study did not find any significant differences among these firms however, Blum (2011) documented that IPO fluctuations are explained by the investor sentiments, capital demand, and prevailing stock market condition. Further, the size of offerings is determined by both firm-specific characteristics and macroeconomic conditions. Consistent with these findings Meluzín et al. (2013) identified the stock market conditions, business sector condition, and investors interest in the business sector as the most important determinants of timing of the public issue. Besides these firms also consider the need for developmental equity capital and state of macroeconomic development while launching IPOs.

\section{Objectives and Hypotheses of the Study}

\subsection{Objectives of the Study}

The main objectives of the study are :

- To examine the general trend in the initial public offerings market in India.

- To examine the influence of prevailing market conditions on preference for IPOs, FPOs, and right issues as a medium to raise funds.

- To examine and compare the growth trend in the number of and fund mobilisation through, IPOs, FPOs, and Right issues and comment on statistical significance thereof.

- To examine and compare the growth trend in the average size of IPO, FPO, and Right issue and comment on statistical significance thereof.

- To perform industry-wise, sector-wise, and instrument-wise analysis of primary market offerings.

\subsection{Hypotheses of the Study}

Consistent with the objectives and scope of the present study, following hypotheses are tested for their statistical significance.

$\mathrm{H}_{01}$ : There is no significant growth trend in the number of IPOs, FPOs, and Right issues during the sample period.

$\mathrm{H}_{02}$ : There is no significant growth trend in fund mobilization via IPOs, FPOs, and Right issues during the sample period.

$\mathrm{H}_{03}$ : Market volatility has no significant impact on number of IPOs, FPOs and right issues, and amount of fund mobilization.

$\mathrm{H}_{04}$ : Present market valuation has no significant impact on the number of IPOs, FPOs and right issues, and amount of fund mobilization.

\section{Research Methodology}

\subsection{Data and Sample}

For the purpose of the present study, historical data has been collected from the annual report of SEBI. The sample comprised of 23 years of data from 1997-2020. The data for years prior to 1997 could not be collected due to its unavailability. 
Trends and Determinants of Primary Market Activities: Evidences from India

\subsection{Statistical Model}

To examine the factors affecting the trend and growth rate under historical trend analysis the following semi-log equation is applied:

$$
\log Y=\alpha+\beta_{1}(t)+\beta_{2}(\text { Sentiment })+\beta_{3}(\ln P E)+u_{t}
$$

In equation (1) the dependent variable is the log transformation of variables viz. number of issues or amount of funds raised through either IPOs, FPOs, or right issues. The equation presents the natural transformation of the dependent variables as a linear combination of factors that influence the number of issues and amount of fund mobilization in the primary market.

\subsection{Research Variables}

The time variable is ordinal scale data which measures the growth rate purely attributed to the passage of time. Regressing log transformation of variables on time will give a regression coefficient $\left(\beta_{1}\right)$ which indicates the percentage change in variables due to one-unit change in time (i.e., year on year). Hence $\left.\left[\exp \left(\beta_{\mathrm{i}}\right)-1\right) * 100\right]$ is the required growth rate. The growth rate explained by other independent variables is interpreted similarly.

Sentiment variable measures the volatility in the market. It is measured by VIX index of BSE Sensex which is calculated on annual basis. The VIX index for a particular period is compared to its average value or a benchmark. A higher than average index value indicates the rising fear and volatility in the market and a lower-than-average value of VIX index indicates less volatility and fear in the market. The market index and VIX index move in the opposite direction. Market return falls as the VIX index rises and vice versa. Hence, a contrarian strategy would mean a buy signal when VIX is significantly higher than the average value and vice versa. Sentiment variable is transformed into a dummy variable based on the average VIX index value for the sample period. If the VIX in a given year is higher than the average value it is assigned the value 1 which means a turbulent market with rising fear and volatility in the market. If the VIX for a given year is either equal to or less than the average then it is assigned the value 0 which indicates a calm market.

$\ln P E$ is the natural $\log$ of PE ratio of BSE Sensex measured on yearly basis. Index PE ratio indicates the state of market valuation. Historically high Index PE ratio could indicate many things, it might signal an overvalued market, the positive investor sentiments are driving the market, or simply the improved future growth prospects. The highest Sensex PE ratio was reported in 1992 at approx. 57.42 and the lowest was reported in 1998 at 9.83. Hence, the market PE ratio gauges the current valuation and investor sentiment. Both the data pertaining to the yearly PE ratio of BSE Sensex and VIX index is taken from the annual report of SEBI.

\section{Results and Data Analysis}

\subsection{Descriptive Analysis}

\subsubsection{Industry Analysis}

Banking and FIs have been the most active industry based on the number of issues made in the primary market. Banking/FIs sector made 251 issues in aggregate which is approximately $12.0 \%$ of 
total issues made during this period ${ }^{1}$. But the variability in the number of issues across the time is also highest for this industry. Information technology and Finance are the second and third most active industries respectively with an overall share of $11.6 \%$ and $9.0 \%$ respectively in the total issue. Following this, the highest number of issues is made by the textile industry (138) and Cement and Construction (134). Which account for $6.6 \%$ and $6.4 \%$ of total issue respectively. The chemical, entertainment, engineering, electric equipment production, and healthcare have also been active in the primary market.

Banks/FIs is also the leader in amount of proceeds raised through primary market issues. The sector raised Rs. 2,02,933 crores which is $26.3 \%$ of total funds mobilised. Followed by this, Finance (Rs. 1,15,385 crores) and Power (Rs. 71,708 crores) sector are the second and third largest sector and funds raised by these industries accounts for $14.9 \%$ and $9.3 \%$ of total funds mobilised. Telecommunication sector although had a smaller number of public issues over 2 decades but the total fund mobilization through this sector holds the fourth largest place. Hence the average amount of fund mobilization in telecommunication industry is a significant figure. Cement and Construction (Rs. 33,451 crores) continues to be at fifth place in ranking and accounted for $4.3 \%$ of total funds raised.

Based on average issue size, telecommunication sector is largest among all with average issue size of Rs. 2463.05 crores followed by Power (Rs. 1792.7 crores), Bank/FIs (Rs. 808.50 crores), Finance (Rs. 617.03 crores) and Cement \& Construction (Rs. 249.63 crores) respectively. The reason is telecommunication sector projects are usually few in numbers and demands a large amount of capital. Power sector also provide elementary support to other sectors of the economy and hence plays a key role. Earlier, government financial support used to be source of finance for Power sector but now it can mobilise the required funds by issuing securities in primary market as well.

As a matter of fact, Finance, Banks, Financial institutions, infrastructure, power, IT and telecommunication are the key sectors of any economy that push economic growth and it is good that primary market is used quite well to fulfil the financial need of these sectors.

Table 1: Most Active Industry by Number of Issues, Total Proceeds and Average Issue Size

\begin{tabular}{llll}
\hline Ranking & & Industry \\
\hline & Based on Number of Issues & $\begin{array}{l}\text { Based on Mobilization } \\
\text { of funds }\end{array}$ & Based on Average Issue Size \\
\hline 1 & Banks/FIs & Banks/FIs & Telecommunication \\
2 & Information \& Technology & Finance & Power \\
3 & Finance & Power & Banks/FIs \\
4 & Textile & Telecommunication & Finance \\
5 & Cement \& Construction & Cement \& Construction & Cement \& Construction \\
\hline
\end{tabular}

Source: Authors' Calculation. Industry rankings on Number of issues, Mobilization of funds and Average issue size are based on calculation presented in Table 2, 3 and 4 respectively. 
Trends and Determinants of Primary Market Activities: Evidences from India

Table 2: Summary Table of Industry Wise Distribution of Issues in Primary Market during 1997-2020

\begin{tabular}{|c|c|c|c|c|c|c|c|c|}
\hline Industry & $N$ & Sum & Mean & Median & Minimum & Maximum & $\begin{array}{r}\text { Std. } \\
\text { Deviation }\end{array}$ & $\begin{array}{r}\% \text { of } \\
\text { Total Sum }\end{array}$ \\
\hline Banks/FIs & 23 & 251 & 10.91 & 11.00 & 0 & 36 & 7.897 & $12.0 \%$ \\
\hline Cementand Construction & 23 & 134 & 5.83 & 4.00 & 0 & 27 & 5.875 & $6.4 \%$ \\
\hline Chemical & 23 & 90 & 3.91 & 4.00 & 0 & 8 & 2.503 & $4.3 \%$ \\
\hline Electrical Equipment Production & 23 & 79 & 3.43 & 3.00 & 0 & 15 & 3.603 & $3.8 \%$ \\
\hline Engineering & 23 & 86 & 3.74 & 3.00 & 0 & 17 & 3.532 & $4.1 \%$ \\
\hline Entertainment & 23 & 73 & 3.17 & 2.00 & 0 & 13 & 3.339 & $3.5 \%$ \\
\hline Finance & 23 & 187 & 8.13 & 5.00 & 0 & 26 & 7.928 & $9.0 \%$ \\
\hline FoodProcessing & 23 & 72 & 3.13 & 2.00 & 0 & 13 & 3.494 & $3.5 \%$ \\
\hline Healthcare & 23 & 91 & 3.96 & 3.00 & 0 & 15 & 3.711 & $4.4 \%$ \\
\hline Information Technology & 23 & 241 & 10.48 & 5.00 & 1 & 89 & 18.815 & $11.6 \%$ \\
\hline Paperand Pulp & 23 & 16 & 0.70 & 0.00 & 0 & 4 & 1.063 & $0.8 \%$ \\
\hline Plastic & 23 & 23 & 1.00 & 0.00 & 0 & 5 & 1.446 & $1.1 \%$ \\
\hline Power & 23 & 40 & 1.74 & 1.00 & 0 & 6 & 2.027 & $1.9 \%$ \\
\hline Printing & 23 & 11 & 0.48 & 0.00 & 0 & 2 & .730 & $0.5 \%$ \\
\hline Telecommunication & 23 & 25 & 1.09 & 1.00 & 0 & 4 & 1.164 & $1.2 \%$ \\
\hline Textile & 23 & 138 & 6.00 & 4.00 & 0 & 19 & 5.649 & $6.6 \%$ \\
\hline Miscellaneous & 23 & 529 & 23.00 & 26.00 & 0 & 62 & 14.740 & $25.4 \%$ \\
\hline
\end{tabular}

Source: Authors' Calculation Based on Historical Data Collected from Annual Reports of SEBI.

Note: $\quad$ some industries viz. Airline, Automobile, Hotels, Insurance, Road and Highways, metals, mining, packaging have been excluded for the unavailability of data for the required period of 1997-2020. Hence, in order to maintain some comparability in analysis these industries were excluded. The total issue, therefore, indicates the total issues made by included industries only.

Table 3: Summary Table Industry Wise Distribution of Amount Mobilised (in Crores of Rupees) during 1997-2020

\begin{tabular}{lrrrrrrrr}
\hline Industry & $N$ & Sum & Mean & Median & Minimum & Maximum & $\begin{array}{c}\text { Std. } \\
\text { Deviation }\end{array}$ Total Sum \\
\hline Banks/FIs & 23 & 202933 & 8823.16 & 4738 & 0 & 30955 & 8922.035 & $26.3 \%$ \\
Cement and Construction & 23 & 33451 & 1454.39 & 275 & 0 & 18905 & 3909.184 & $4.3 \%$ \\
Chemical & 23 & 7792 & 338.80 & 153 & 0 & 2085 & 495.608 & $1.0 \%$ \\
Electrical Equipment Production & 23 & 10973 & 477.09 & 96 & 0 & 4218 & 981.889 & $1.4 \%$ \\
Engineering & 23 & 10400 & 452.15 & 217 & 0 & 1992 & 544.561 & $1.3 \%$ \\
Entertainment & 23 & 10335 & 449.33 & 154 & 0 & 2461 & 590.092 & $1.3 \%$ \\
Finance & 21 & 115385 & 5494.52 & 1826 & 30 & 35644 & 8695.220 & $14.9 \%$ \\
Food Processing & 23 & 8045 & 349.78 & 71 & 0 & 1978 & 523.688 & $1.0 \%$ \\
\hline
\end{tabular}

contd. table 3

Orissa Journal of Commerce, 42(3) (C) 2021 
Lovleen Gupta and Sheetal Maurya

\begin{tabular}{lrrrrrrrr}
\hline Industry & $N$ & Sum & Mean & Median & Minimum & Maximum & $\begin{array}{c}\text { Std. } \\
\text { Deviation }\end{array}$ & $\begin{array}{r}\% \text { Total Sum } \\
\text { Healthcare }\end{array}$ \\
Information Technology & 23 & 20477 & 890.28 & 144 & 0 & 5500 & 1614.311 & $2.7 \%$ \\
Paper and Pulp & 23 & 18574 & 807.54 & 315 & 4 & 5095 & 1162.737 & $2.4 \%$ \\
Plastic & 23 & 908 & 39.49 & 0 & 0 & 306 & 81.326 & $0.1 \%$ \\
Power & 23 & 1140 & 49.56 & 0 & 0 & 500 & 114.853 & $0.1 \%$ \\
Printing & 23 & 71708 & 3117.74 & 15 & 0 & 25293 & 6306.993 & $9.3 \%$ \\
Telecommunication & 23 & 451 & 19.60 & 0 & 0 & 130 & 38.549 & $0.1 \%$ \\
Textile & 23 & 61576 & 2677.23 & 11 & 0 & 49970 & 10363.341 & $8.0 \%$ \\
Miscellaneous & 23 & 8386 & 364.61 & 207 & 0 & 1335 & 398.471 & $1.1 \%$ \\
\hline
\end{tabular}

Source: Authors' Calculation Based on Historical Data Collected from Annual Reports of SEBI.

Note: $\quad$ some industries viz. Airline, Automobile, Hotels, Insurance, Road and Highways have been excluded for the unavailability of data for the required period of 1997-2020. Hence, in order to maintain some comparability in analysis these industries were excluded. The total issue, therefore, indicates the total issues made by included industries only.

Table 4: Summary Table of Average Issue Size (in Crores of Rupees) by Various Industry: During 1997-2020

\begin{tabular}{lrrr}
\hline Industry & TotalFunds raised & Total Number of issues & Average Issue Size \\
\hline Banks/FIs & 202932.61 & 251 & 808.50 \\
Cement and Construction & 33451.01 & 134 & 249.63 \\
Chemical & 7792.4 & 90 & 86.58 \\
Electrical Equipment/Production & 10973.04 & 79 & 138.90 \\
Engineering & 10399.53 & 86 & 120.92 \\
Entertainment & 10334.69 & 73 & 141.57 \\
Finance & 115385.02 & 187 & 617.03 \\
Food Processing & 8045.05 & 72 & 111.74 \\
Healthcare & 20476.55 & 91 & 225.02 \\
Information Technology & 18573.5 & 241 & 77.07 \\
Paper and Pulp & 908.19 & 16 & 56.76 \\
Plastic & 1139.88 & 23 & 49.56 \\
Power & 71708.1 & 40 & 1792.70 \\
Printing & 450.83 & 11 & 40.98 \\
Telecommunication & 61576.25 & 25 & 2463.05 \\
Textile & 8385.96 & 138 & 60.77 \\
Miscellaneous & 190084.27 & 529 & 359.33 \\
\hline
\end{tabular}

Source: Authors' Calculation Based on Historical Data Collected from Annual Reports of SEBI.Note: some industries viz. Airline, Automobile, Hotels, Insurance, Road and Highways have been excluded for the unavailability of data for the required period of 1997-2020. Hence, in order to maintain some comparability in analysis these industries were excluded. 


\subsubsection{Sectoral Analysis}

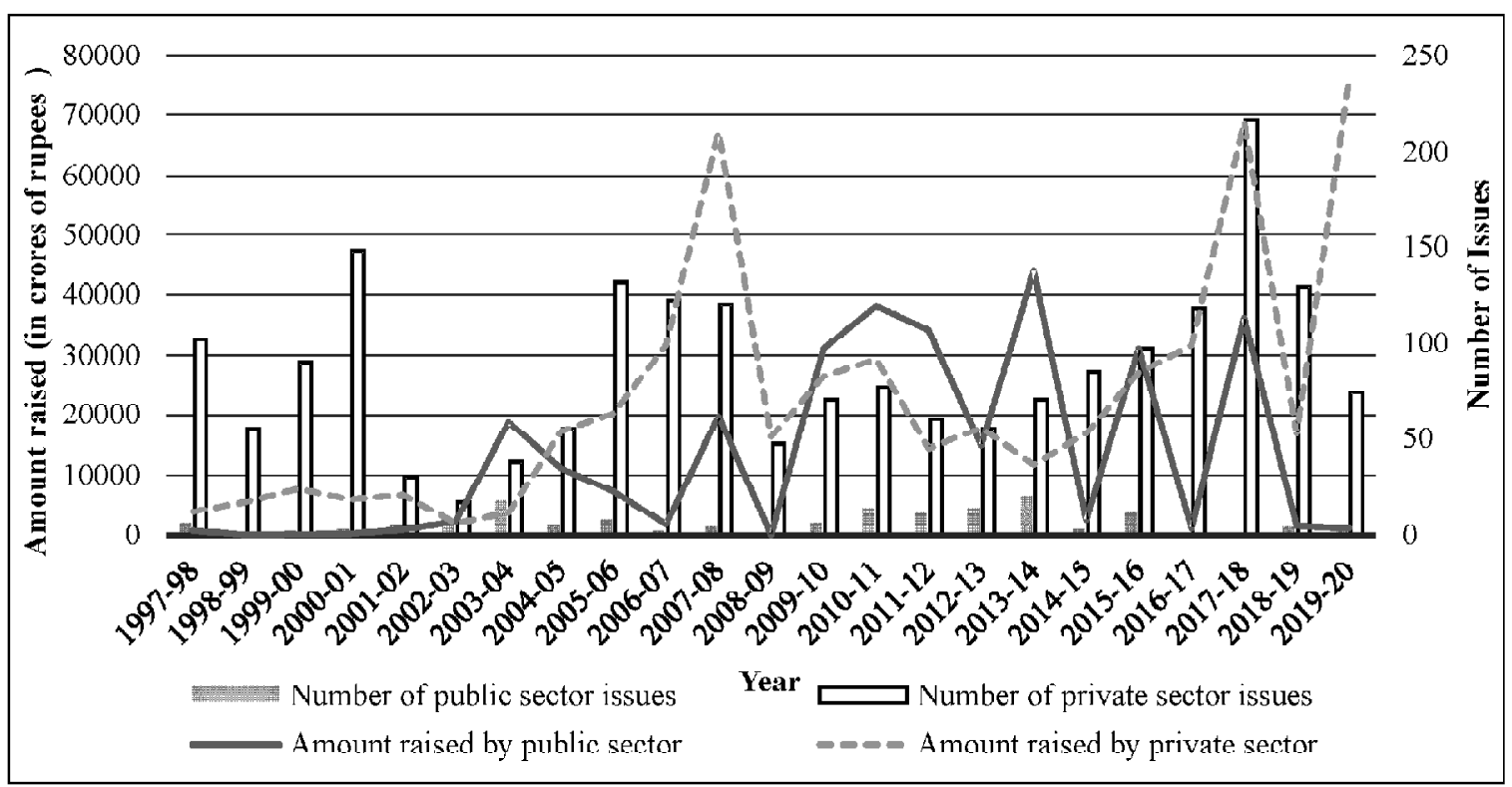

Figure 1: Sectoral Distribution of Number of Issues Funds in Primary Market

Source: Authors' Compilation

Table 5 presents the descriptive analysis of the sectoral distribution of issues. As can be easily observed the private sector dominates the primary market, for during 1997-2020 there were total 2006 issues from private sector as against merely 149 issues from public sector.

Also, the variability in number of issues per year is less for private sector (C.V. is $51.55 \%$ ) as compared to that of the public sector (C.V. is $87.552 \%$ ). It is also evident that variability is less in the number of issues, but it increases significantly in the amount of funds raised and this is true for both private sector and public-sector issues. However, variability in amounts of funds raised continues to be greater for the public sector (coefficient of variance is $117.143 \%$ ) as compared to $92.510 \%$ for that of the private sector. It is interesting to note that, although the private sector dominates in terms of the number of issues and total fund mobilization, the average issue size for the period 1997-2020 is significantly higher for the public sector (Rs. 2003.452 crores as against only Rs. 261.217 crores for private sector). This is because public issues are few in number but large in capital requirement.

\subsubsection{Instrument Wise Break Up of Issues in Capital Market}

Table 6 exhibits the descriptive summary of instrument-wise trend observed during 1997-2020. During this period IPO has been the most commonly made issue followed by Right issue, and FPO. In aggregate 1358 IPOs, 518 Right issues, and 258 FPOs have been made since 1997. And the maximum amount of 
Lovleen Gupta and Sheetal Maurya

Table 5: Summary Table of Sectoral Distribution for the Period 1997-2020

(Amount in Crores of Rupees)

\begin{tabular}{lrrrr}
\hline & \multicolumn{2}{c}{ Public Sector } & \multicolumn{2}{c}{ Private Sector } \\
\hline Statistics & $\begin{array}{r}\text { Number of } \\
\text { issues }\end{array}$ & $\begin{array}{r}\text { Amount } \\
\text { (Rs. crores) }\end{array}$ & $\begin{array}{r}\text { Number of } \\
\text { issues }\end{array}$ & $\begin{array}{r}\text { Amount } \\
\text { (Rs. crores) }\end{array}$ \\
\hline $\mathrm{N}$ & 23 & 23 & 23 & 23 \\
Mean & 6.478 & 12978.884 & 87.217 & 22782.696 \\
Median & 5 & 2446 & 77 & 16756 \\
Sum & 149 & 298514.34 & 2006 & 524002.02 \\
Minimum & 0 & 0 & 17 & 1895.52 \\
Maximum & 20 & 43970 & 216 & 75850 \\
Std. Deviation & 5.671 & 15203.866 & 44.960 & 21076.339 \\
Skewness & 1.061 & 0.84108 & 0.973 & 1.562 \\
Coefficient of Variance (\%) & 87.552 & 117.143 & 51.550 & 92.510 \\
Percent of Total Issue & $6.91 \%$ & $36.29 \%$ & $93.09 \%$ & $63.71 \%$ \\
Average Issue Size & \multicolumn{2}{c}{2003.452} & & 261.217 \\
\hline
\end{tabular}

Source: Authors' Calculation Based on Historical Data Collected from Annual Reports of SEBI.

fund is mobilised through IPOs (Rs. 3,52,200.65 crores) followed, Right Issues (Rs. 1,95,068.01 crores) and FPOs (Rs. 1,19,697.80 crores).The average issue size of IPO is the least amongst three (i.e., Rs. 259.352crores).

Looking at the variability in the number of issues made and amount of funds raised over time, right issues have the least variability in number of right issues made every year (C.V. is $45.16 \%$ ) and FPOs has the most variability in number of FPOs made every year (151.88\%). That means Right issue has the most consistent distribution of issues since 1997. There is found to be quite significant variability in distribution of fund mobilization for all three types of issues, but it is least in case of IPOs (C.V. is $127.00 \%)$.

\subsection{Historical Trends Analysis}

Historical trend analysis studies the contributors to the growth rate in the number of IPOs, amount of funds raised via IPOs, and the average size of an IPO. To get a comparative view, the growth rate in FPOs and Right Issues is also studied on identical variables. The sample comprised of 17 data points and the same has been collected from the annual reports of SEBI. Due to the unavailability of data on some of the explanatory variables the sample includes data for the period of 2003-2020. The methodology used to study the historical trend in the present chapter is adapted from (Singh, 2017).

This section is organised into three subsections viz. initial public offerings, follow-on public offerings and right issue. Model 1 measures the compounded annual growth rate in the dependent 
Trends and Determinants of Primary Market Activities: Evidences from India

Table 6: Descriptive Statistics of Public and Right Issues (Amount is in rupees crores)

\begin{tabular}{|c|c|c|c|c|c|c|}
\hline \multirow[t]{3}{*}{ Statistics } & \multicolumn{4}{|c|}{ Public Issues } & \multicolumn{2}{|c|}{ Right Issues } \\
\hline & \multicolumn{2}{|c|}{$I P O$} & \multicolumn{2}{|c|}{ FPO } & & \\
\hline & $\begin{array}{l}\text { Number } \\
\text { of Issues }\end{array}$ & $\begin{array}{r}\text { Amount } \\
\text { Raised }\end{array}$ & $\begin{array}{l}\text { Number } \\
\text { of Issues }\end{array}$ & $\begin{array}{l}\text { Amount } \\
\text { Raised }\end{array}$ & $\begin{array}{l}\text { Number } \\
\text { of Issues }\end{array}$ & $\begin{array}{l}\text { Amount } \\
\text { Raised }\end{array}$ \\
\hline $\mathrm{N}$ & 23 & 23 & 23 & 23 & 23 & 23 \\
\hline Mean & 59.0435 & 15313.0717 & 11.2174 & 5204.2522 & 22.5217 & 8481.2178 \\
\hline Median & 51 & 6528 & 2 & 3385.41 & 22 & 3711 \\
\hline Minimum & 6 & 404.21 & 0 & 0 & 8 & 193.61 \\
\hline Maximum & 201 & 83684.00 & 59 & 22040.00 & 49.00 & 55642.00 \\
\hline Std. Deviation & 45.258 & 19447.473 & 17.037 & 6596.216 & 10.171 & 12758.238 \\
\hline Skewness & 1.529 & 2.219 & 1.669 & 1.246 & 0.806 & 2.803 \\
\hline Sum & 1358 & 352200.65 & 258 & 119697.80 & 518 & 195068.01 \\
\hline CV $(\%)$ & $76.65 \%$ & $127.00 \%$ & $151.88 \%$ & $126.75 \%$ & $45.16 \%$ & $150.43 \%$ \\
\hline Average & \multicolumn{2}{|c|}{259.352} & \multicolumn{2}{|c|}{463.945} & \multicolumn{2}{|c|}{376.579} \\
\hline
\end{tabular}

Source: Authors' Calculation Based on Historical Data Collected from Annual Reports of SEBI.

variable as a function of time. Model 2 incorporates the sentiment and market PE ratio as the explanatory variables along with the time factor. The results from model 2 exhibit a significant improvement in $\mathrm{R}$ square of the model. The interpretations of partial regression coefficients are presented below.

\subsubsection{Initial Public Offerings}

Results of the 'time only' model in Table 7 show that the number of initial public offerings has grown at a rate of $7.1 \%$ p.a. compounded annually. A low p-value implies that the trend component in data on the number of IPOs is statistically significant at $5 \%$. However, a significant drop in adjusted R square might be due to the omission of other relevant explanatory variables. Adjusted R square in Model 2 increases significantly due to incorporation of sentiment and market PE variables to $61.8 \%$ from $24.8 \%$ and the model is also statistically significant at $1 \%(\mathrm{p}$-value $=0.001)$. In model specification 2 , market PE ratio is statistically significant at $1 \%$. This indicates that the growth rate in the number of initial public offerings is significantly higher during the period of high market valuation. However, the trend and sentiment factors are found to be insignificant. When taken in isolation in Model 1, the trend component does show a significant growth trend and the model is statistically significant at $5 \%$. However, the presence of sentiment and market PE ratio weakens the effect of the trend component. This suggests that issuers look for the opportunity and the market appears to be overvalued. The decision to launch a public offering is less affected by the market volatility during the period of high market valuation. Although, the growth trend in the number of IPOs over a period of study is significant, but the pattern is significantly moderated by the prevailing market conditions. Owing to the great volatility in fund mobilization through IPOs, there is no significant growth trend. The amount of fund 


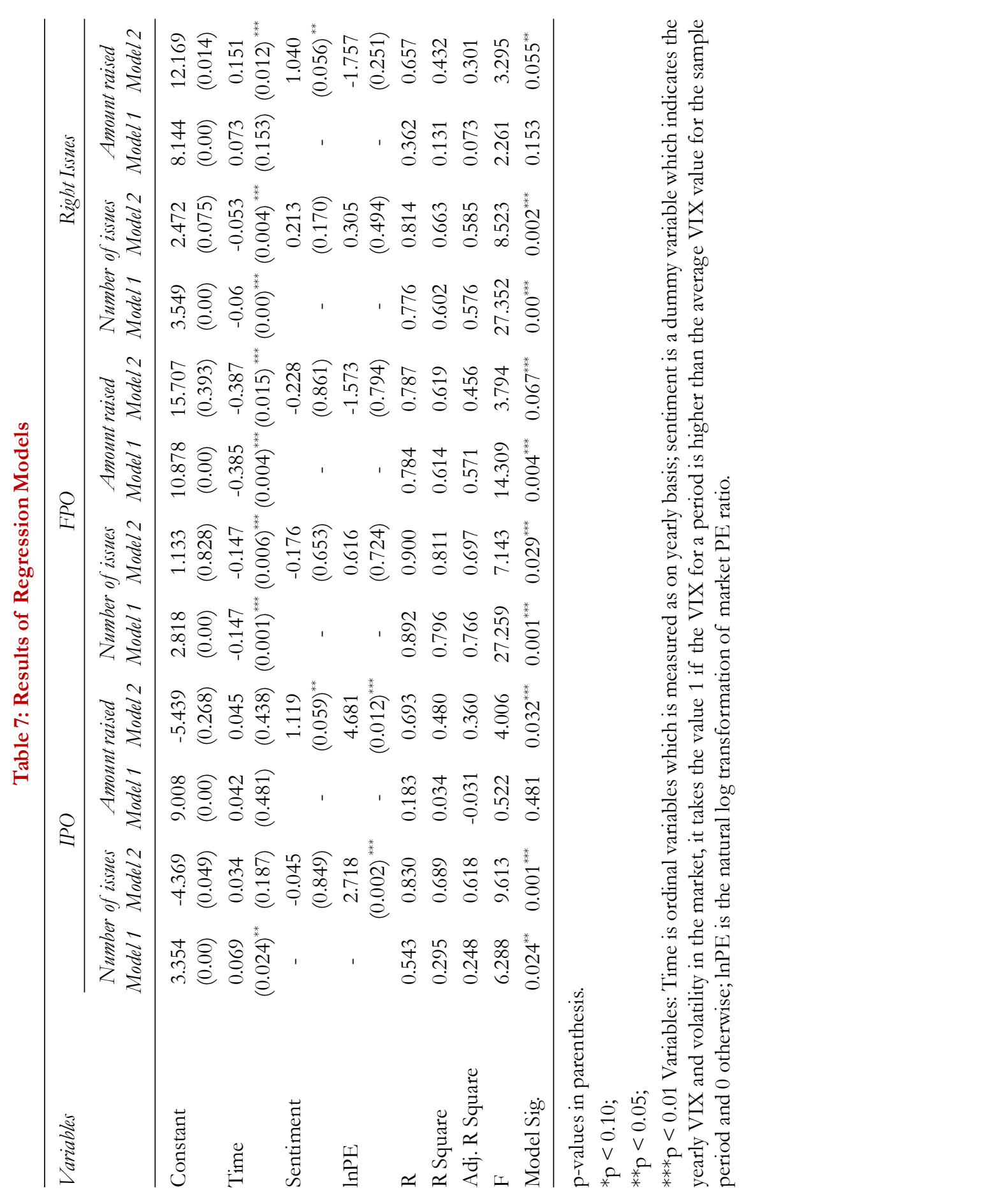


mobilization is largely affected by the investor sentiment and prevailing market valuation. As expected, fund mobilization is significantly higher for the period of high market valuation. Contrary to the expectation, the average fund mobilization during the period of high market volatility and rising market fear is significantly higher than during a relatively calm market.

\subsubsection{Follow-on Public Offerings}

The number of follow-on public offerings and proceed raised through FPOs has declined at a rate of $-13.7 \%$ p.a. and $32 \%$ p.a. respectively. It appears that the decision to go for follow-on public offering is less affected by the prevailing market conditions and more by the available profitable opportunity. Both sentiment and valuation of the market are reported to be insignificant in case of FPOs. Burgstaller (2009) found that prevailing interest rates and corporate indebtedness are significant determinants of seasoned equity offerings in both statistical and economic terms. However, the trend component is found to be statistically significant. Over the period of study both the number of FPOs and amount of fund mobilization has been declining.

\subsubsection{Right Issues}

Similar to FPOs, the number of right issues has been declining at a rate of $5.8 \%$ p.a. this trend is statistically significant. The decision to announce a right issue is less affected by the prevailing market conditions rather the management decisions based on requirement of funds and availability of investment opportunities appear to have greater bearing on right issues. This can be seen in the insignificant slope coefficients of other two explanatory variables in model 2 . Although the number of right issues is declining the amount of fund mobilization has grown at a rate of $7.6 \%$ p.a. However, trend only model 1 is insignificant. On the other hand, model specification 2 is statistically significant and improvise the $\mathrm{R}$ square from 0.131 to 0.432 . Although the slope coefficient of market sentiment is statistically significant, the low value of adjusted $R$ Square (0.301) requires to maintain the status quo that decision to do fund mobilizations through right issue is majorly affected by the unique business opportunity and management consensus.

\section{Conclusion}

The present study reveals that the private sector has clear dominance over the public sector in the new issue market. Approximately $93 \%$ of the public offerings over the past two decades were from private sector firms. However, the public sector still mobilises far more aggregate funds than the private sector. Therefore, the average issue size of public sector firms is higher than that of private-sector firms. In terms of sectoral concentration banks/FIs, information and technology, textile, cement and construction, and telecommunications are the key sectors. Further, variability in public sector issues in terms of the number of offering per year and the issue size is far greater than the private sector.

For the period of 2003-2020, the number of initial public offerings has grown at an annual compounded rate of $7.1 \%$. However, owing to the great volatility in fund mobilization through IPOs, there is no significant growth trend. The growth in the number of public issues attributed to the time component is also statistically significant. However, a low adjusted $\mathrm{R}$ square indicates the omission of 
other relevant explanatory variables. The revised model with market variables significantly improves the explanatory power of the model. Statistical significance of market PE ratio indicates that the growth rate in the number of initial public offerings is significantly higher during the period of high market valuation. This confirms the market timing hypothesis as reported in previous studies such as Ritter (1984); Loughran and Ritter (1995); Ritter and Welch (2002); Baker and Wurgler (2000) and Burgstaller (2003). However, the trend and sentiment factors are found to be insignificant.

It is observed that the decision to launch a public offering is less affected by the market volatility during the period of high market valuation. Although, the growth trend in number of IPOs over a period of study is significant, but the pattern is significantly moderated by the prevailing market conditions. On the other hand, the amount of fund mobilization through IPOs is largely affected by the investor sentiment and prevailing market valuation and it is significantly higher for the period of high market valuation. In cases of seasoned or follow-on public offering and right issues, prevailing market conditions are reported to have an insignificant effect. It appears that decisions to raise funds through seasoned public offering and right issues are largely affected by unique business opportunities and management consensus. Both the number of FPOs and right issues have declined over the period of study.

Hence, the present study confirms the market timing hypothesis in case of initial public offerings, however seasoned public offerings and right issues might be affected by other variables also such as prevailing interest rates and corporate indebtedness.

\section{Note}

1. The total issue indicates the total issues made by included industries only.

\section{References}

Alti, A. (2005). IPO Market Timing. Review of Financial Studies, 18, 1105-1138. doi:10.1093/RFS/HHI022.

Babich, V., \& Sobel, M. J. (2004). Pre-IPO Operational and Financial Decisions. Management Scienc, 50(7), 935 948. Retrieved from https://www.jstor.org/stable/30047950.

Baker, M., \& Wurgler, J. (2000). The Equity Share in New Issues and Aggregate Stock Returns. The journal of Finance, 55(5), 2219-2257. Retrieved from https://doi.org/10.1111/0022-1082.00285.

Batnini, F., \& Hammami, M. (2015). IPO waves: How market performances influence the market timing of IPO? Journal of Applied Business Research, 31(5), 1679-1692. doi:10.19030/jabr.v31i5.9382.

Benninga, S., Helmantel, M., \& Sarig, O. (2005). The timing of initial public offerings. Journal of Financial Economics, 75(1), 115-132.

Bhanumurthy, K. V., \& Singh, A. K. (2008). IPO Pricing: Informational Inefficiency and Misallocation in Capital Market. Retrieved from https://ssrn.com/abstract=1303409 or http://dx.doi.org/10.2139/ssrn.1303409.

Blum, R. (2011). IPO Timing Determinants. Durham, North Carolina. Retrieved from https:// dukespace.lib.duke.edu.

Brau, J. C., \& Fawcett, S. E. (2004). Initial Public Offerings: An Analysis of Theory and Practice. The Journal of Finance, 61(1), 399-434. doi:10.2139/ssrn.530924

Burgstaller, J. (2003). When and why do Austrian companies issue shares? . Economics working papers 2005-03, Johannes Kepler University , Department of Economics, Linz, Austria. Retrieved from https://ideas.repec.org/p/ jku/econwp/2005_03.html. 
Burgstaller, J. (2009). When and why do Austrian companies issue shares? Empirica, 36(3), 229-244. doi:10.1007/ s10663-008-9082-3.

Gupta, L., Mohapatra, A. K., \& Maurya, S. (2020). Long-run Operating Performance of Firms and IPO Underpricing: Evidences from India. The Empirical Economics Letters, 19(8), 871-882.

He, P. (2007). A Theory of IPO Waves. The Review of Financial Studies, 20(4), 983-1020. Retrieved from http:// www.jstor.org/stable/4494794.

Latham, S., \& Braun, M. (2010). To IPO or Not to IPO: Risks, Uncertainty and the Decision to Go Public. British Journal of Management, 21(3), 666-683. doi:10.1111/j.1467-8551.2010.00707.x.

Loughran, T., \& Ritter, J. R. (1995). The New Issues Puzzle. Journal of Finance, 50(1), 23-51.

Loughran, T., Ritter, J., \& Rydqvist, K. (1994). Initial public offerings: International insights. Pacific-Basin Finance Journal, 2(2-3), 165-199.

Lowry, M. (2003). Why does IPO volume fluctuate so much? Journal of Financial Economics, 67(1), 3-40. Retrieved from https://doi.org/10.1016/S0304-405X(02)00230-1.

Lowry, M., \& Schwert, G. W. (2002). IPO Market Cycles: Bubbles or Sequential Learning? Journal of Finance, 67(3), 1171-1200.

Maurya, S. (2017). IPO Grading in India: A Review of Literature. In A. K. Singh, Emerging Issues and Challenges in Finance (pp. 55-78). Galgotia Publishing Company.

Meluzín, T., \& Zinecker, M. (2013). Trends in IPOs: The Evidence From Financial Markets. Equilibrium, Quarterly Journal of Economics and Economic Policy, 8(2), 45-63.

Meluzín, T., Zinecker, M., \& Kovandová, S. (2013). IPO Timing Determinants: Empirical evidence on Polish capital market. Acta Universitatis Agriculturae et Silviculturae Mendelianae, 61(7), 2499-2506. Retrieved from http://dx.doi.org/10.11118/actaun201361072499.

Rajan, R., \& Servaes, H., 1995. The effect of market conditions on initial public offerings. Working paper, University of Chicago and University of North Carolina at Chapel Hill.

Ritter, J. R., \& Welch, I. (2002). A review of IPO activity, pricing, and allocations. Journal of Finance, 57(4), 17951828.

Ritter, J. R. (1984). The 'Hot Issue' Market of 1980. Journal of Business, 57(2), 215-240.

Singh, A. K. (2017). Growth Performance of Indian IPO Market since Liberalisation. Asian Journal of Management, 8(3), 753-760.

Singh, A. K., \& Maurya, S. (2018). Corporate Governance, Ownership Structure, and IPO Underpricing: Evidence from the Indian New Issue Market. Indian Journal of Research in Capital Markets, 5(1), 7-24. doi:10.17010/ ijrcm/2018/v5/i1/122905.

Singh, A. K., Maurya, S., \& Mohapatra, A. K. (2019). IPO Underpricing and Predictive Power of Board Related Corporate Governance Mechanisms: A Study of Indian IPO Market. Theoretical Economics Letters, 9(6), 20022018. doi:10.4236/tel.2019.96127. 